\title{
Distribution of carbon and nitrogen along hillslopes in three valleys on Herschel Island, Yukon Territory, Canada
}

\author{
Justine L. Ramage $\mathrm{e}^{\mathrm{a}, \mathrm{b}, \mathrm{d}, *}$, Daniel Fortier ${ }^{\mathrm{c}}$, Gustaf Hugelius ${ }^{\mathrm{d}, \mathrm{e}}$, Hugues Lantuit ${ }^{\mathrm{a}, \mathrm{b}}$, \\ Anne Morgenstern ${ }^{\mathrm{a}}$ \\ a Department of Permafrost Research, Alfred Wegener Institute Helmholtz Centre for Polar and Marine Research, Potsdam, Germany \\ ${ }^{\mathrm{b}}$ University of Potsdam, Institute of Geoscience, Potsdam, Germany \\ ${ }^{\mathrm{c}}$ Université de Montréal, Department of Geography, Montreal, Canada \\ ${ }^{\mathrm{d}}$ Department of Physical Geography, Stockholm University, Stockholm, Sweden \\ e Bolin Center for Climate Research, Stockholm University, Stockholm, Sweden
}

\section{A R T I C L E I N F O}

\section{Keywords:}

Hillslope thermokarst

Soil organic carbon storage

Catchment geomorphology

Permafrost degradation

\begin{abstract}
A B S T R A C T
Thermokarst results from the thawing of ice-rich permafrost and alters the biogeochemical cycling in the Arctic by reworking soil material and redistributing soil organic carbon (SOC) and total nitrogen (TN) along uplands, hillslopes, and lowlands. Understanding the impact of this redistribution is key to better estimating the storage of SOC in permafrost terrains. However, there are insufficient studies quantifying long-term impacts of thaw processes on the distribution of SOC and TN along hillslopes. We address this issue by providing estimates of SOC and TN stocks along the hillslopes of three valleys located on Herschel Island (Yukon, Canada), and by discussing the impact of hillslope thermokarst on the variability of SOC and TN stocks. We found that the average SOC and TN 0-100 cm stocks in the valleys were $26.4 \pm 8.9 \mathrm{~kg} \mathrm{C} \mathrm{m}^{-2}$ and $2.1 \pm 0.6 \mathrm{~kg} \mathrm{~N} \mathrm{~m}-{ }^{2}$. We highlight the strong variability in the soils physical and geochemical properties within hillslope positions. High SOC stocks were found at the summits, essentially due to burial of organic matter by cryoturbation, and at the toeslopes due to impeded drainage which favored peat formation and SOC accumulation. The average carbon-to-nitrogen ratio in the valleys was 12.9, ranging from 9.7 to 18.9 , and was significantly higher at the summits compared to the backslopes and footslopes ( $\mathrm{p}<0.05$ ), suggesting a degradation of SOC downhill. Carbon and nitrogen contents and stocks were significantly lower on $16 \%$ of the sites that were previously affected by hillslope thermokarst ( $\mathrm{p}<0.05$ ). Our results showed that lateral redistribution of SOC and TN due to hillslope thermokarst has a strong impact on the SOC storage in ice-rich permafrost terrains.
\end{abstract}

\section{Introduction}

The global permafrost region occupies ca. $15 \%$ of the terrestrial Earth surface (Gruber, 2012), and stores more than twice the amount of carbon contained in the atmosphere (Schuur et al., 2015). In the northern circumpolar permafrost region, the most recent estimates show that soil organic carbon (SOC) storage in the upper $3 \mathrm{~m}$ is $1035 \pm 150 \mathrm{Pg}$ (Hugelius et al., 2014). Near-surface permafrost in the high Arctic has warmed by $>0.5^{\circ} \mathrm{C}$ between 20072009 and 2017 (AMAP, 2017), triggering permafrost thaw, increasing the degradation of soil organic matter (SOM), and the emissions of greenhouse gases a process known as the permafrost carbon feedback (Schaefer et al., 2014). The permafrost carbon feedback can be compensated by the increase in the total nitrogen (TN) stocks following permafrost thaw, which favors plant growth and offsets carbon losses (Koven et al,, 2015). Permafrost thaw in ice-rich permafrost terrains can lead to thermokarst, a process resulting in collapse and subsidence of the surface due to melting of the ground ice. Hillslope thermokarst in Arctic catchments has increased (Lamoureux and Lafrenière, 2009; Lantz and Kokelj, 2008; Rudy et al., 2013; Coch et al., 2018b), and altered the biogeochemical cycling by reworking soil material and redistributing SOC and nutrients along hillslopes (Kokelj et al., 2013; Lamoureux and Lafrenière, 2014; Larouche et al., 2015; Woods et al., 2011).

SOC estimates for the circumpolar permafrost region overlooks the very high spatial variability of permafrost SOC storage (Palmtag et al., 2016; Siewert et al., 2015) and poorly accounts for SOC storage on hillslopes and in mountain regions (Hugelius et al., 2014; Mishra et al., 2013). Our main objective is thus to gain an understanding of the

\footnotetext{
* Corresponding author at: Department of Permafrost Research, Alfred Wegener Institute Helmholtz Centre for Polar and Marine Research, Potsdam, Germany.

E-mail address: Justine.ramage@nordregio.org (J.L. Ramage).
} 


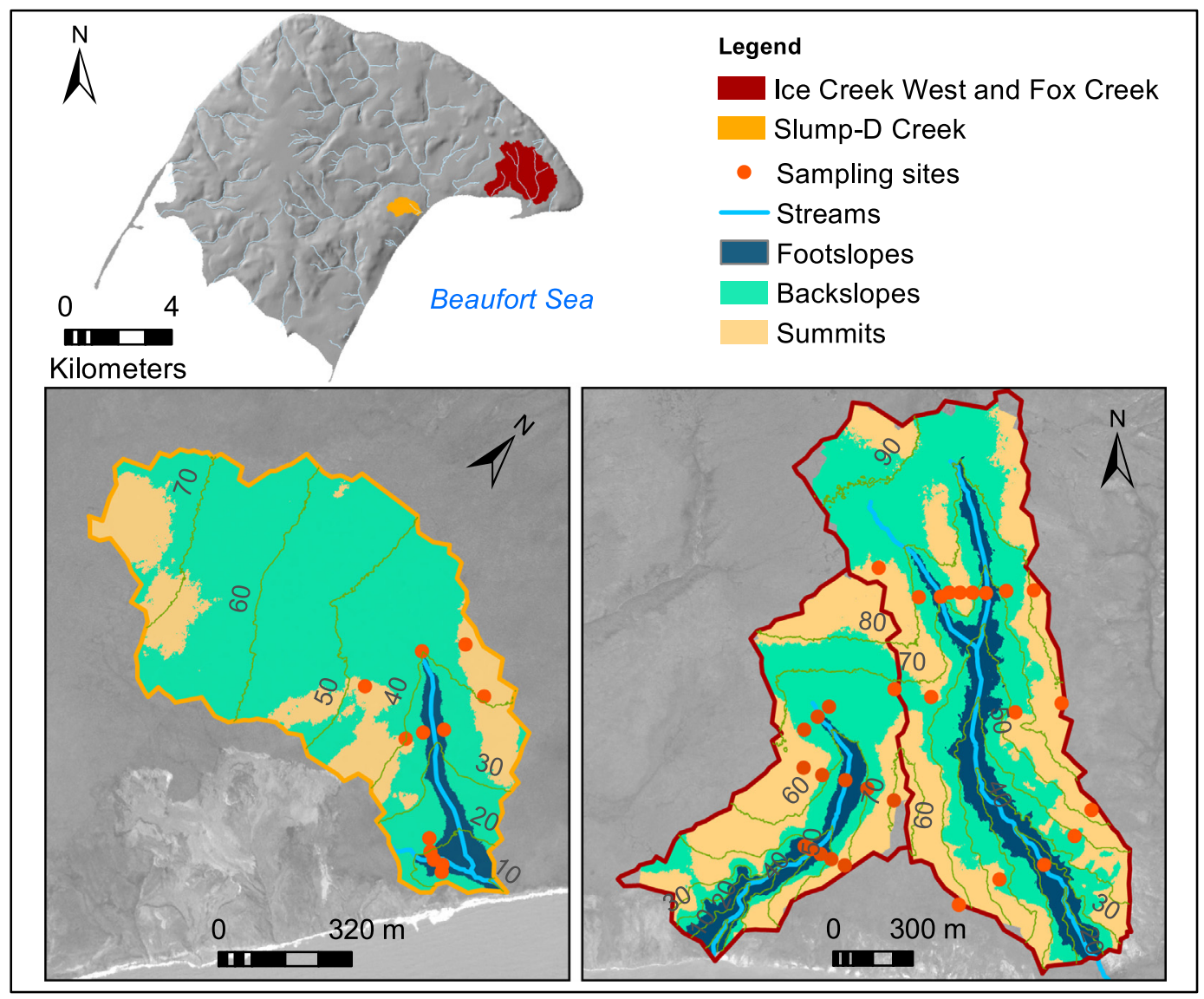

Fig. 1. Map of Herschel Island and of the 3 studied valleys (A): Ice Creek West (ICW) (B), Fox Creek (FC) (C), and Slump-D Creek (SLD) (D). The valleys are located on the eastern sector of the island and drain into the Beaufort Sea. Each basin is divided into 4 hillslope positions; the summits, backslopes, footslopes and toeslopes. For better visualization the backslopes and footslopes are combined on this figure. Sampling sites were distributed along transects located upstream, midstream, and downstream, intersecting the valleys perpendicularly.

spatial variability of SOC and TN stocks in sloping terrains to improve the estimates of SOC storage in the permafrost region. To quantify the contribution of hillslope thermokarst (retrogressive thaw slumps (RTS) and active layer detachment slides (ALDS)) to modifying the SOC storage in the landscape, we first described hillslope topographies and identified hillslope thermokarst within three valleys located in ice-rich permafrost terrains on Herschel Island (Yukon, Canada). Second, we assessed the distribution of SOC and TN along hillslopes in these valleys, and we related this distribution to spatial, soil, and environmental parameters.

\section{Study area}

Herschel Island (Qikiqtaruk Territorial Park) is located in the western Canadian Arctic, $2 \mathrm{~km}$ off the Yukon Coastal plain (Fig. 1). The island of ca. $111 \mathrm{~km}^{2}$ is characterized by rolling and hummocky moraines, modified by periglacial processes (MacKay, 1959). Ridges and hills reach up to $178 \mathrm{~m}$ a.s. 1 inland, and steep cliffs up to $60 \mathrm{~m}$ characterize the coasts. The coasts are eroding, with a mean coastal retreat rate of $0.45 \pm 0.48 \mathrm{~m} / \mathrm{yr}$ between 1970 and 2000 (Lantuit and Pollard, 2008), and $0.68 \pm 2.48 \mathrm{~m} / \mathrm{yr}$ between 2000 and 2011 (Obu et al., 2016). The marine deposits forming Herschel Island were pushed up the surface by the Laurentide Ice Sheet during its advance from the Herschel Basin to the margin of the glaciated area. Part of the permafrost on Herschel Island is therefore old, pre-dating the formation of the island (Burn, 2000). Preglacial deposits are marine and terrestrial sediments. Glacial and postglacial deposits include till, erratic boulders, peat accumulation and alluvial deposits (Bouchard, 1974). Most of the soils are Turbic
Cryosols (Canadian Soil Classification System; Soil Classification Working Group, 1998), with well developed, but variable, organic surface horizons underlain by mineral clayey-silt soils (Bouchard, 1974). Burial of surface organic horizons into the mineral subsoil through cryoturbation is prevalent (Bouchard, 1974). Ground ice is present throughout the island except on beaches and spits. Volumetric ground ice contents vary from $44 \%$ to $77 \%$ (Couture and Pollard, 2017) and mostly occur as pore ice, segregated ice lenses, ice wedges, and massive icy beds (Pollard, 1990). Mean SOC and TN stocks for the upper meter of soil are estimated for Herschel Island to $34.8 \mathrm{~kg} \mathrm{C} \mathrm{m}^{-2}$ and $3.4 \mathrm{~kg} \mathrm{~N} \mathrm{~m}^{-2}$, respectively (Obu et al., 2017). Geomorphological hillslope processes occur in the form of retrogressive thaw slumps, active layer detachment slides, thermal erosion gullies, and solifluction, impacting the vegetation (Obu et al., 2017). The Herschel ecological unit, characterizing hummocky tussock tundra, is the climax vegetation community of the island and is generally located on the uplands (Smith et al., 1989). The mean annual air temperature for the period 2000-2017 along the Yukon Coast was $-10^{\circ} \mathrm{C}$ in Komakuk (west of Herschel Island) and $-9^{\circ} \mathrm{C}$ at Shingle Point (east of Herschel Island), while July and August daily average was $7.6^{\circ} \mathrm{C}$ in Komakuk and $10{ }^{\circ} \mathrm{C}$ at Shingle Point (Environment Canada, 2017). Annual precipitation between 1971 and 2000 was low, varying between 150 and $200 \mathrm{~mm}$ (Burn and Zhang, 2009). The snow cover on Herschel Island is thin as a result of low precipitation, strong winds, and low surface roughness. The snow is blown away from the uplands and accumulates in topographic depressions (Burn and Zhang, 2009). Late winter snow depth on the uplands was on average $17 \mathrm{~cm}$ with a range of $10-26 \mathrm{~cm}$ between 1999 and 2007. Snowmelt occurs in late May or early June 
(Burn, 2012) and is the largest hydrological event of the year (Coch et al., 2018a).

The island is divided into 40 main watersheds with mean drainage basins of 73.2 ha, ranging from 20.4 to 2697.7 ha (Ramage, 2017). Fieldwork took place along the eastern coast of Herschel Island, in three valleys (Ice Creek West, Fox Creek, and Slump-D Creek), representative in size of the valleys of Herschel Island (Ramage, 2017). To our knowledge, there is no published data on the origin of the valleys on Herschel Island. As many Arctic watersheds, the valleys on Herschel Island have a nival flow regime (Woo, 1986). In summer, discharge is mostly controlled by rainfall, when occasional rainfall events may lead to high discharge over short periods of time (Coch et al., 2018a).

\section{Methods}

We evaluated the spatial distribution of SOC and TN in the studied valleys by first describing the valley and hillslope topographies and then collecting soil samples along predefined transects through the valleys. Finally, we related these data using statistical analyses.

\subsection{Valley geomorphology}

The streams on Herschel Island were mapped using a high-resolution GeoEye- 1 satellite image $(1.8 \mathrm{~m}$ resolution in multi-spectral and $0.5 \mathrm{~m}$ in panchromatic views) acquired on August 31st 2011 (Ramage, 2017). Streams, from the source to the outlet, were manually mapped at a nominal scale of 1:2000. Spatial analyses were performed in ArcMap version 10.3 (ESRI, Redlands, CA, USA). We used a Digital Elevation Model (DEM) from TanDEM-X created in 2012 (12 m resolution and $4 \mathrm{~m}$ vertical absolute accuracy, German Aerospace Center (DLR)) to delineate the watersheds and derive spatial information (slope gradient, elevation, aspect) (Table 2). We created three transects intersecting each valley perpendicularly, in the upstream, midstream, and downstream sections (Fig. 2). We divided the valley hillslopes into four hillslope positions as defined by Schoeneberger et al. (2012) using field observations and the topographic position index tool (TPI) with a threshold of $100 \mathrm{~m}$ (Fig. 2). The TPI compares the elevation of each cell in a DEM to the mean elevation of a specified neighborhood around that cell. Positive (respectively, negative) TPI values define areas that are higher (respectively, lower) than the average of their surroundings. TPI values near zero are either flat or low sloping areas (Guisan et al.,
1999). The four hillslope positions are the summits (threshold values between 2.6 and 10.7), the backslopes (threshold values between -1.2 to 2.6), the footslopes (threshold values between -6.0 and -1.2 ) and the toeslopes (threshold values between -19.3 and -6.0 ).

\subsection{Sampling scheme}

Soil samples were collected between July 27th and August 8th, 2015 in three valleys on Herschel Island (Fig. 1). Along each transect we established three to five sampling sites at each hillslope position (Fig. 2).

At each site, we systematically described the vegetation and excavated soil pits (ca. $50 \mathrm{~cm} \times 50 \mathrm{~cm}$ ) down to the frost table or to $1 \mathrm{~m}$ depth. We measured the depth of the active layer for each soil pit, as the depth to the top of the frost table on the sampling day. We described the soil horizons in the active layer (e.g. sediment type, structure) and sampled each soil genetic horizon using fixed volume cylinders (diameter $=3.4 \mathrm{~cm}$, height $=3.8 \mathrm{~cm}$ ). The organic surface horizon was cut out and measured for volume. To collect permafrost samples, we hammered a steel pipe (diameter $=4.2 \mathrm{~cm}$ ) from the top of the frost table to a depth of $1 \mathrm{~m}$ at $10 \mathrm{~cm}$ increments. For each sample, we qualitatively described the level of cryoturbation if applicable. We assigned a relative level of cryoturbation ( 1 - low to 3 - high cryoturbation) based on thorough observations of the profile and samples as described in Siewert (2016). Soil horizons were identified as affected by carbon enriched cryoturbations if the carbon enrichment in the sample was confirmed in the laboratory. We sampled 43 sites and collected 316 samples (Supplementary Material S2). The samples were kept cool $\left(<6{ }^{\circ} \mathrm{C}\right)$ and were transported to the laboratory for further analysis.

\subsection{Geochemical analyses}

Soil samples were freeze-dried for $72 \mathrm{~h}$ at $-20^{\circ} \mathrm{C}$. We weighed the samples before and after freeze-drying to determine their volumetric water content. We estimated the dry bulk density $\left(\rho_{b}\right)$ using Eq. (1), where $\mathrm{dW}_{\mathrm{i}}$ is the dry-weight of a sample and $\mathrm{V}_{\mathrm{i}}$ its volume.

$\rho_{\mathrm{b}}=\mathrm{dW}_{\mathrm{i}} / \mathrm{V}_{\mathrm{i}}$

The samples were analyzed separately for organic carbon (OC\%) and nitrogen (N\%) contents in a carbon-nitrogen analyzer (Vario EL III elemental analyzer, Elementar ${ }^{\circledR}$, measuring range $\left.<40 \mathrm{ppm}\right)$. The

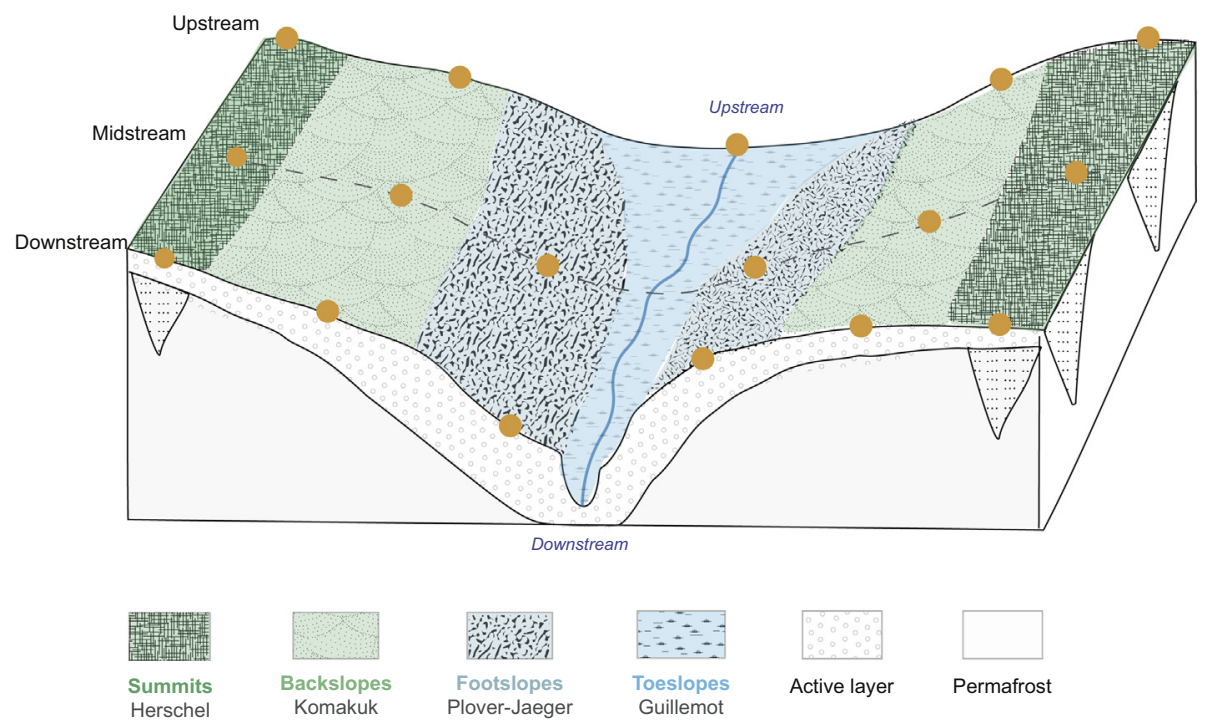

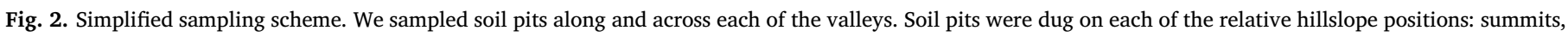
backslopes, footslopes, and toeslopes. Ecological classes associated to these units are indicated below each unit. 
total organic carbon (TOC) was measured using a carbon analyzer (Vario Max C analyzer, Elementar ${ }^{\circledR}$, precision of 10 ppm C in soil). SOC was then calculated using Eq. (2), where \%TOC is the total organic carbon content ( $w t \%), \rho_{b}$ the dry bulk density, and $L$ the length of a sample $(\mathrm{cm})$.

$\mathrm{SOC}=\% \mathrm{TOC}^{*} \rho_{\mathrm{b}}{ }^{*} \mathrm{~L}^{*} 10$

The carbon-to-nitrogen ratio $(\mathrm{C} / \mathrm{N})$ was calculated using the ratio between \%TOC and $\% \mathrm{~N}$. The $\mathrm{C} / \mathrm{N}$ ratio can be used as an index for the potential degradability of SOM stored in permafrost soils and the potential for carbon loss upon thaw, high $\mathrm{C} / \mathrm{N}$ ratio indicating slow decomposition of SOM (Schädel et al., 2014; Kuhry and Vitt, 1996). Stable carbon isotopes $\left(\delta^{13} \mathrm{C}\right)$ values were analyzed with a DELTAplusXL Finnigan mass spectrometer (Thermo Fisher Scientific ${ }^{\circledast}$, Germany) coupled to a Carlo-Erba NC2500 elemental analyzer. Isotope signatures are reported in per mille (\%o) against Vienna Pee Dee Belemnite standard (VPDB).

\subsection{Data analyses}

We tested the dependency of SOC, TN, OC\%, N\%, and C/N ratio against environmental and spatial variables (Table 1). These variables were either characterized and described in the field (active layer depth, level of cryoturbation, vegetation), derived from laboratory analyses (volumetric water content, bulk density), or extracted from geospatial products (hillslope position, slope orientation, topographic wetness index, and hillslope disturbances). Hillslope position classification was adjusted from direct field observations using the TPI. To account for the influence of past or current hillslope disturbances on the sampling sites, we used the dataset provided by Coch et al. (2018b) in which ALDS and RTS in the valleys are mapped for the years 1952, 1970, 2011, and 2015.

Normality of distributions was tested by applying the Shapiro-Wilk normality test. The impact of the spatial position (spatial variables) on the geochemical variables was assessed using the Kruskal-Wallis nonparametric test and Dunn's post-hoc test. These tests were chosen because the dependent variables were not all normally distributed. Pearson linear correlations between soil and geochemical variables were performed and tested for significant linear relationships using student $t$-tests. All tests were performed using the R software (The R Foundation, version 3.3.1).

\section{Results}

\subsection{Geomorphology of the valleys}

\subsubsection{Longitudinal profiles}

The drainage basins of the studied valleys - Slump-D Creek (SLD), Fox Creek (FC), and Ice Creek (IC) - were respectively 61.8 ha, 77.5 ha, and 309.1 ha, ranging in elevation from $0 \mathrm{~m}$ to $80 \mathrm{~m}$ a.s.l. FC and ICW

\section{Table 1}

Variables used in the statistical analyses. Hillslope disturbances (active layer detachment slides and thaw slumps) were mapped for the years 1952, 1970, 2011 and 2015 in Coch et al. (2018a, 2018b).

\begin{tabular}{|c|c|c|}
\hline Type & Abbreviation & Signification \\
\hline Spatial & HSP & $\begin{array}{l}\text { Hillslope position: summits, backslopes, footslopes, } \\
\text { toeslopes }\end{array}$ \\
\hline Spatial & DS & $\begin{array}{l}\text { Relative distance of the transect to the shore: upstream, } \\
\text { midstream, downstream }\end{array}$ \\
\hline Spatial & PAIR & Slope orientation: east- and west-facing slopes \\
\hline Spatial & DIST & Hillslope disturbances (1: presence; 0 : absence) \\
\hline Soil & $\mathrm{AL}$ & Active layer depth $(\mathrm{cm})$ \\
\hline Soil & CRY & Level of cryoturbation (scale: 1 , low to 3 , high) \\
\hline Soil & VWC & Volumetric water content (\%) \\
\hline Soil & TWI & Topographic wetness index \\
\hline
\end{tabular}

Table 2

Geomorphic characteristics of the studied valleys on Herschel: Ice-Creek West (ICW), Fox-Creek (FC) and Slump-D Creek (SLD).

\begin{tabular}{llll}
\hline Valley & ICW & FC & SLD \\
\hline Drainage basin $\left(\mathrm{km}^{2}\right)$ & 3.09 & 0.77 & 0.62 \\
Stream number & 4 & 5 & 6 \\
Total stream length (m) & 3569 & 1688 & 1786 \\
Stream order 1 & 2 & 4 & 4 \\
Stream order 2 & 1 & 1 & 1 \\
Stream order 3 & 1 & 0 & 1 \\
Drainage density (km ${ }^{-1}$ ) & 1.15 & 2.19 & 2.88 \\
Valley width upstream (m) & 483 & 103 & 497 \\
Valley width midstream (m) & 456 & 312 & 484 \\
Valley width downstream (m) & 612 & 313 & 177 \\
Differential elevation upstream E-facing slope (m) & 11.35 & 4.04 & 8.19 \\
Differential elevation upstream W-facing slope (m) & 16.46 & 3.27 & 3.60 \\
Differential elevation midstream E-facing slope (m) & 21.55 & 12.49 & 9.59 \\
Differential elevation midstream W-facing slope (m) & 31.47 & 15.49 & 9.78 \\
Differential elevation downstream E-facing slope (m) & 33.65 & 6.14 & 2.11 \\
Differential elevation downstream W-facing slope (m) & 41.19 & 17.83 & 5.72 \\
Main stream & & & \\
Length (m) & 2511 & 1396 & 960 \\
Gradient ( ${ }^{\circ}$ Elevation max (m) & 1.6 & 2.6 & 3 \\
Elevation min (m) & 81 & 67.9 & 55 \\
\hline & 0 & 0 & 0 \\
\hline & & & \\
\hline
\end{tabular}

were oriented north-south and SLD west-east. The three valleys drain directly into the Herschel Basin in the Beaufort Sea (Fig. 1). Stream gradients ranged between $1.6^{\circ}$ and $3.0^{\circ}$ (Table 2). The upper and middle parts of the valleys had gentle, convex, stabilized, and vegetated hillslopes with increasing slope gradient downstream (Table 2). In the upper part of the valleys the streams were narrow (ca. $10 \mathrm{~cm}$ wide). Thermo-erosional processes created U-shaped channels, and low stream gradients developing into beaded streams. In the midstream and downstream parts of the valleys, ALDS, RTS, and solifluction lobes were common along hillslopes. In the midstream parts of the valleys, hillslope runoff through water tracks was the main supply for the widening streams (ca. $50 \mathrm{~cm}$ wide). Where streams incised the valley floor deeper, the water table was lower. On the segments where streamflow increased, knickpoints formed, the vegetation was absent, and pebbles and cobbles were visible reflecting stronger erosion. In their downstream parts, the valleys evolved as ravines, with steep, non-vegetated, and asymmetric hillslopes. In late July 2015 the streams at the outlet were up to $100 \mathrm{~cm}$ wide and ca. $10 \mathrm{~cm}$ deep.

\subsubsection{Transverse profile}

The valley hillslopes were concavo-convex, with relatively smooth profiles and no abrupt breaks (Fig. 3). The backslopes were concave, characterized by erosional processes. The footslopes were convex, characterized by sediment accumulation deposited from uphill. In the midstream and downstream parts of the valleys, ALDS and RTS were common. The slope profiles were gradual. Slope asymmetries were present in the valleys: west and north-facing slopes had lower gradients and were more vegetated than east and south-facing slopes (Fig. 4, Table 2).

The summits were characterized by stable flat surfaces where little erosion had occurred. They had shallow active layers and hummocky surfaces covered by cottongrass and moss vegetation (so-called Herschel ecological class). The most common type of soil was Turbic Cryosol, with peat covered silty clays. The soils were moist or moderately-well drained. Non-sorted patterned-ground occurred and cryoturbation was common throughout the soil profiles.

The backslopes comprised terrains undergoing moderate erosion. Hillslope thermokarst (RTS and ALDS), solifluction lobes, and patterned-ground (stripes, earth-hummocks and frost-boils) were present on all slopes. These processes contributed to creating heterogeneous geomorphological conditions. Consequently, soils were reworked and soil-forming processes were interrupted in some areas, forming Static 


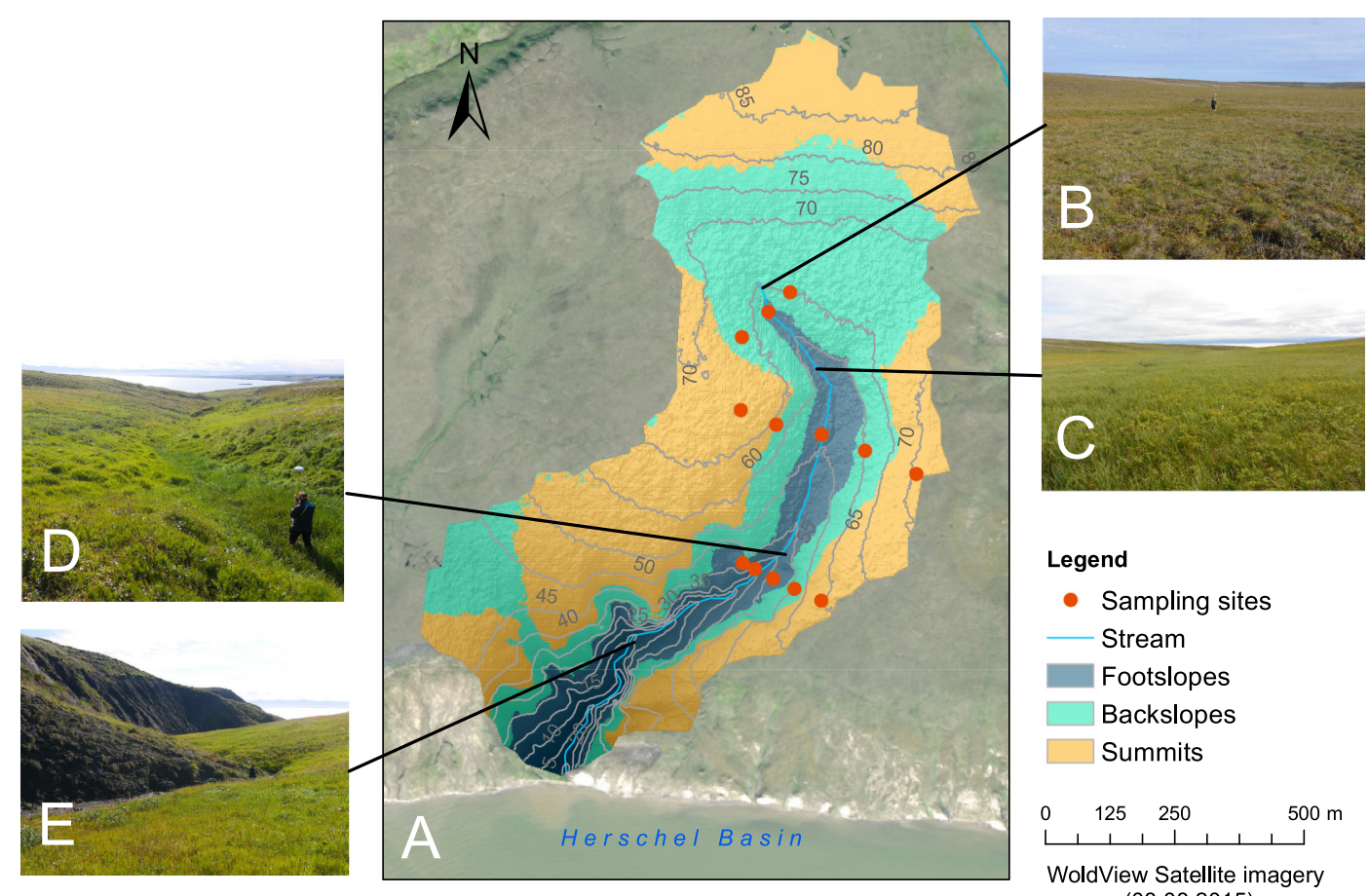

(08.08.2015)

Fig. 3. Morphology of a valley, Fox Creek (FC). (A) The map shows the different valley units (defined using the Topographic Position Index) and the sampling locations. The underlying image is a WorldView satellite image from August 8th 2015. The photographs were taken on August 4th 2015 and show the valley in the (B) upstream, (C and D) midstream, and (E) downstream. Person for scale (Photos by S. Stettner).

Cryosols that lacked developed horizons. Some of the soils located in the upper part of the backslopes were Turbic Cryosols.

The footslopes were characterizing terrains bordering the valley floors. The footslopes were zones of soil accumulation being deposited from the backslopes by mass movements. Soils were composed of a thin organic layer $(<5 \mathrm{~cm})$ and a thick uniform mineral horizon $(>70 \mathrm{~cm})$. Static Cryosols were the most common soil type at the footslopes. The common ecological unit at the footslopes and backslopes was PloverJaeger with Arctic willows covering non-eroded soils.

The toeslopes were sampled in the upstream and midstream parts of the valleys. Upstream, they were characterized by longitudinal depressions formed by the degradation of ice-wedges. The toeslopes were covered by sedge-grass vegetation (so-called Guillemot ecological class) developed on saturated or poorly drained soils. The conditions were hygric with a high water table located a few centimeters under the surface. These soils developed fibric peat layers $(>30 \mathrm{~cm})$ with high organic content.
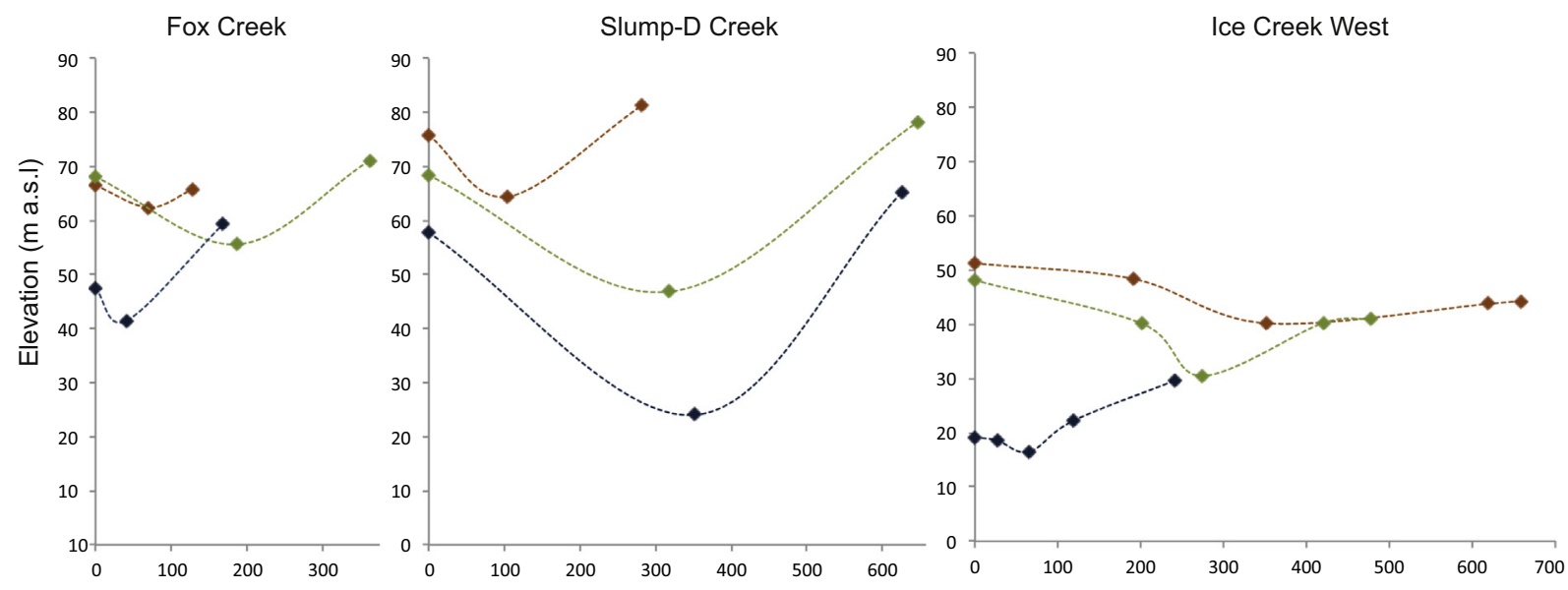

Valley width $(\mathrm{m})$

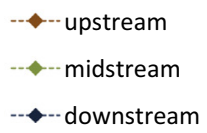

Fig. 4. Transverse profiles of the three studied valleys on Herschel Island. The profiles were traced in the upstream, midstream and downstream parts of the valleys. Slope asymmetries are present in the valleys: west-facing slopes have lower gradients than east-facing slopes. 


\subsection{Spatial variability in soils characteristics and geochemical parameters}

\subsubsection{Active layer depth}

The mean active layer depth in the valleys was $52.2 \pm 20.2 \mathrm{~cm}$, ranging between $26 \mathrm{~cm}$ and $>100 \mathrm{~cm}$, with the deepest active layers found at the footslopes (Table 4). There was no significant difference in the mean active layer depth between the east and west-facing slopes (Supplementary Material S5). However, active layers at the summits were significantly thinner than on the hillslopes (Table 4, p < 0.05). The toeslopes and summits had similar active layer depths of ca. $41.1 \pm 8.7 \mathrm{~cm}$ (Supplementary Material S5).

\subsubsection{Carbon and nitrogen contents}

The OC\% and N\% decreased with increasing depth and were higher in the active layer than in the permafrost (Table 4). The TN stocks and N\% were significantly higher on the east-facing slopes $\left(2.3 \pm 0.6 \mathrm{~kg} \mathrm{~N} \mathrm{~m}^{-2}\right.$ and $0.6 \pm 0.2 \%$, respectively) compared to the west-facing slopes $\left(1.9 \pm 0.4 \mathrm{~N} \mathrm{~kg} \mathrm{~m}^{-2}\right.$ and $0.4 \pm 0.1 \%$, respectively). In the permafrost, SOC and TN stocks were significantly higher on the east-facing slopes $\left(13.5 \pm 8.7 \mathrm{~kg} \quad \mathrm{C}^{-2}\right.$ and $1.0 \pm 0.5 \mathrm{~kg} \mathrm{~N} \mathrm{~m}^{-2}$, respectively) compared to the west-facing slopes $\left(7.1 \pm 5.0 \mathrm{~kg} \mathrm{C} \mathrm{m}^{-2}\right.$ and $0.6 \pm 0.3 \mathrm{~kg} \mathrm{~N} \mathrm{~m}^{-2}$, respectively). The OC\% was significantly higher on the upstream transects compared to the downstream transects, especially in the active layer. Along hillslopes, the largest OC\%, N\%, SOC, and TN stocks were found at the toeslopes, which were characterized by peat accumulation and water saturated soils (Table 3). The OC\% was significantly higher at the toeslopes compared to the footslopes and the N\% significantly higher at the toeslopes compared to the backslopes and footslopes (Table 3). On the contrary, significantly low OC\% and N\% were found at the footslopes that were characterized by deposition of material from the backslopes.

The mean soil $\mathrm{C} / \mathrm{N}$ ratio across all sites was $12.8 \pm 2.2$, ranging from 9.7 to 18.9. Individual pits showed a decrease in $\mathrm{C} / \mathrm{N}$ ratios with increasing depth (Supplementary Material S2). The $\mathrm{C} / \mathrm{N}$ ratio in the active layer was significantly higher than in the permafrost (Table 4). The $\mathrm{C} / \mathrm{N}$ ratios were significantly higher on the upstream transect compared to the midstream and downstream transects and, also, at the summits compared to the backslopes and footslopes (Table 3). There was no significant difference in $\mathrm{C} / \mathrm{N}$ ratios between sites located at the toeslopes and other hillslope positions (Table 3 ). The soil $\delta^{13} \mathrm{C}$ values in our study sites were relatively homogeneous and typical of a C3-plant dominant ecosystem, ranging between $-28.9 \%$ and $-26.3 \%$. The C/ $\mathrm{N}$ ratios and $\delta^{13} \mathrm{C}$ values were negatively correlated $(\mathrm{r}=-0.58$, $\mathrm{p}<0.05)$.

\subsection{Impact of ALDS and RTS on the geochemical parameters}

ALDS and RTS were identified on $16 \%$ of the hillslope sites (Table 5), mainly located at the backslopes and footslopes (Fig. 5, Table 6). Most of the ALDS and RTS that were active in 1952 and/or 1972 were stabilized in 2011 and 2015. The active layer depths were significantly greater $(\mathrm{p}<0.05)$ on sites previously affected by hillslope thermokarst. Carbon and nitrogen contents and stocks were significantly lower ( $\mathrm{p}<0.05$ ) on sites previously affected by ALDS and RTS (Table 5). There were no significant differences between the $\mathrm{C} / \mathrm{N}$ ratios and $\delta^{13} \mathrm{C}$ signatures from sites previously affected by ALDS and RTS compared to other sites (Table 5). There were no disturbances identified at the summits and only one at the toeslsopes (Table 6). ALDS and RTS mostly occurred at the backslopes and footslopes. At the backslopes impacted by disturbances, the active layer depths were significantly deeper $(\mathrm{p}<0.05)$ and the SOC and TN content significantly higher $(\mathrm{p}<0.05)$ than at the backslopes that had not been impacted by disturbances. The same pattern was found at the footslopes where the SOC and TN contents, $\% \mathrm{C}, \% \mathrm{~N}$, and $\mathrm{C} / \mathrm{N}$ ratios were higher at the sites that had not been affected by disturbances in the past (Table 6).

\subsection{Correlations between soil characteristics and geochemical variables}

The volumetric water content decreased and the bulk density increased from upstream to downstream in the valleys. Along hillslopes, the volumetric water content and level of cryoturbation decreased, and the bulk densities increased from upslope to downslope sites. Geochemical variables were well correlated to the soil characteristics (Table 7). Among all soil characteristics, the level of cryoturbation was the most correlated to the geochemical variables (Table 7). Moist and strongly cryoturbated sites (as identified in the field) had higher SOC and TN stocks, $\mathrm{C} \%, \mathrm{~N} \%$, and $\mathrm{C} / \mathrm{N}$ ratios. The $\mathrm{C} \%$ and $\mathrm{N} \%$ as well as $\mathrm{C} / \mathrm{N}$ ratio were negatively correlated to the depth of the active layer. Sites with thin active layers had the highest $\mathrm{C} \%, \mathrm{~N} \%$ and $\mathrm{C} / \mathrm{N}$ ratios. The $\mathrm{C} / \mathrm{N}$ ratio was positively correlated to the volumetric water content and the topographic wetness index.

\section{Discussion}

\subsection{Spatial variability of SOC and TN stocks in sloping terrains}

Our study based on the analysis of 43 hillslope sites located across three valleys on Herschel Island highlights the spatial variability of carbon and nitrogen storage along catena. The average SOC and TN $0-100 \mathrm{~cm}$ stocks in our study area were $26.4 \pm 8.9 \mathrm{~kg} \mathrm{C} \mathrm{m}^{-2}$ and

Table 3

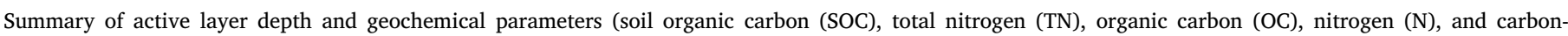

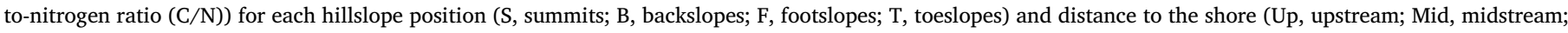
Down, downstream) averaged for the three valleys. Mean values are reported with \pm one standard deviation.

\begin{tabular}{|c|c|c|c|c|c|c|c|c|}
\hline & & Sites (n) & $\mathrm{AL}(\mathrm{cm})$ & $\mathrm{SOC}\left(\mathrm{kg} \mathrm{m}^{2}\right)$ & $\mathrm{TN}\left(\mathrm{kg} \mathrm{m}^{2}\right)$ & OC content (\%) & $\mathrm{N}$ content $(\%)$ & $\mathrm{C} / \mathrm{N}$ \\
\hline \multirow{3}{*}{$S$} & Up & 4 & $39.5 \pm 7.4$ & $28.7 \pm 1.9$ & $2.1 \pm 0.1$ & $10.6 \pm 2.8$ & $0.6 \pm 0.2$ & $14.7 \pm 1.5$ \\
\hline & Mid & 9 & $41.8 \pm 8.7$ & $26.9 \pm 8.1$ & $2.1 \pm 0.5$ & $8.4 \pm 3.2$ & $0.5 \pm 0.2$ & $13.3 \pm 2.0$ \\
\hline & Down & 5 & $41.2 \pm 11.6$ & $26.2 \pm 5.6$ & $2.0 \pm 0.4$ & $10.0 \pm 3.8$ & $0.6 \pm 0.1$ & $14.4 \pm 2.9$ \\
\hline \multirow{3}{*}{ B } & Up & 0 & NA & NA & NA & NA & NA & NA \\
\hline & Mid & 10 & $58.5 \pm 19.6$ & $25.5 \pm 10.7$ & $2.2 \pm 0.6$ & $7.8 \pm 2.1$ & $0.5 \pm 0.1$ & $11.9 \pm 1.5$ \\
\hline & Down & 6 & $56 \pm 15.7$ & $24.9 \pm 10.9$ & $2.1 \pm 0.7$ & $5.5 \pm 3.4$ & $0.4 \pm 0.2$ & $11.5 \pm 1.7$ \\
\hline \multirow{3}{*}{$\mathrm{F}$} & Up & 0 & NA & NA & NA & NA & NA & NA \\
\hline & Mid & 1 & $100 \pm \mathrm{NA}$ & $24.7 \pm \mathrm{NA}$ & $2.6 \pm \mathrm{NA}$ & $6.2 \pm \mathrm{NA}$ & $0.5 \pm \mathrm{NA}$ & $10.7 \pm \mathrm{NA}$ \\
\hline & Down & 3 & $92.6 \pm 12.7$ & $16.4 \pm 5.8$ & $1.6 \pm 0.6$ & $4.7 \pm 3.9$ & $0.3 \pm 0.1$ & $11.1 \pm 1.8$ \\
\hline \multirow{3}{*}{$\mathrm{T}$} & Up & 2 & $37.0 \pm 2.8$ & $33.1 \pm 6.7$ & $2.3 \pm 0.6$ & $12.8 \pm 0.9$ & $0.8 \pm 0.1$ & $15.3 \pm 2.5$ \\
\hline & Mid & 2 & $37.5 \pm 4.9$ & $27.9 \pm 6.9$ & $2.0 \pm 0.2$ & $10.3 \pm 5.3$ & $0.7 \pm 0.3$ & $13.7 \pm 2.3$ \\
\hline & Down & 1 & $57 \pm \mathrm{NA}$ & $46.7 \pm \mathrm{NA}$ & $3.7 \pm \mathrm{NA}$ & $10.2 \pm \mathrm{NA}$ & $0.8 \pm \mathrm{NA}$ & $12.5 \pm \mathrm{NA}$ \\
\hline
\end{tabular}


Table 4

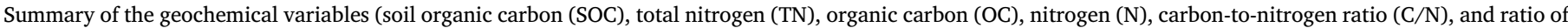

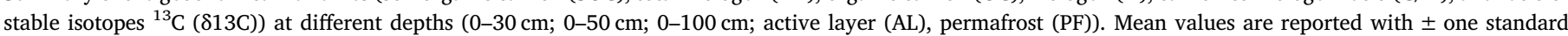
deviation.

\begin{tabular}{|c|c|c|c|c|c|c|}
\hline Depth/soil type & $\left.\operatorname{SOC}(\mathrm{kg} \mathrm{C} \mathrm{m})^{2}\right)$ & $\mathrm{TN}\left(\mathrm{kg} \mathrm{N} \mathrm{m}^{2}\right)$ & OC (\%) & N (\%) & $\mathrm{C} / \mathrm{N}$ & $\delta^{13} \mathrm{C}(\%)$ \\
\hline $0-30 \mathrm{~cm}$ & $11.4 \pm 3.7$ & $0.8 \pm 0.3$ & $15.4 \pm 11.9$ & $0.9 \pm 0.4$ & $17.7 \pm 6.4$ & $-28.0 \pm 1.2$ \\
\hline $0-50 \mathrm{~cm}$ & $17.9 \pm 4.9$ & $1.4 \pm 0.4$ & $14.9 \pm 11.8$ & $0.8 \pm 0.4$ & $15.9 \pm 5.9$ & $-27.7 \pm 1.2$ \\
\hline $0-100 \mathrm{~cm}$ & $26.4 \pm 8.9$ & $2.1 \pm 0.6$ & $8.3 \pm 3.5$ & $0.5 \pm 0.2$ & $12.9 \pm 2.2$ & $-27.1 \pm 0.6$ \\
\hline $\mathrm{AL}$ & $16.2 \pm 4.6$ & $1.3 \pm 0.4$ & $13.4 \pm 11.9$ & $0.7 \pm 0.5$ & $15.1 \pm 6.0$ & $-27.6 \pm 1.1$ \\
\hline PF & $11.2 \pm 1.8$ & $0.9 \pm 0.1$ & $6.8 \pm 5.0$ & $0.4 \pm 0.3$ & $12.1 \pm 2.9$ & $-26.9 \pm 0.7$ \\
\hline
\end{tabular}

Table 5

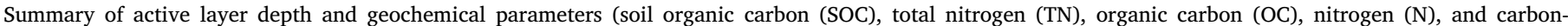

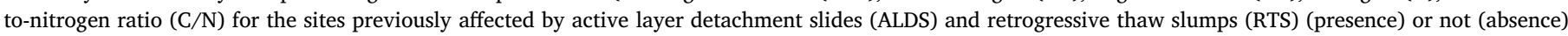

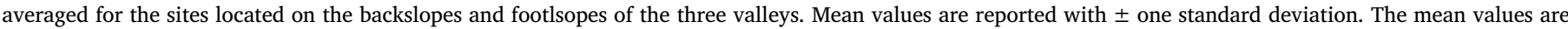

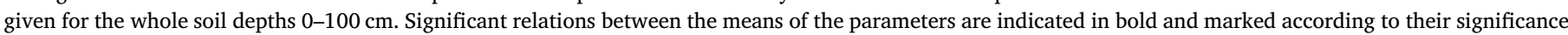
level: ***p $<0.001 ; * * \mathrm{p}<0.05 ; * \mathrm{p}<0.1$

\begin{tabular}{|c|c|c|c|c|c|c|c|}
\hline & Sites (n) & AL mean $(\mathrm{cm})$ & $\operatorname{SOC}\left(\mathrm{kg} \mathrm{C} \mathrm{m}{ }^{2}\right)$ & $\mathrm{TN}\left(\mathrm{kg} \mathrm{N} \mathrm{m}^{2}\right)$ & OC content (\%) & $\mathrm{N}$ content $(\%)$ & $\mathrm{C} / \mathrm{N}$ \\
\hline Absence & 36 & $55.0 \pm 19.6^{* *}$ & $28.0 \pm 9.4^{* *}$ & $2.3 \pm 0.6^{* *}$ & $8.1 \pm 2.9^{* *}$ & $0.6 \pm 0.2^{* *}$ & $12.4 \pm 1.8^{* * *}$ \\
\hline Presence & 7 & $73.6 \pm 25.1^{* *}$ & $20.3 \pm 11.6^{* *}$ & $1.8 \pm 0.7^{* *}$ & $5.8 \pm 4.4^{* *}$ & $0.4 \pm 0.3^{* *}$ & $11.3 \pm 1.9^{* *}$ \\
\hline
\end{tabular}

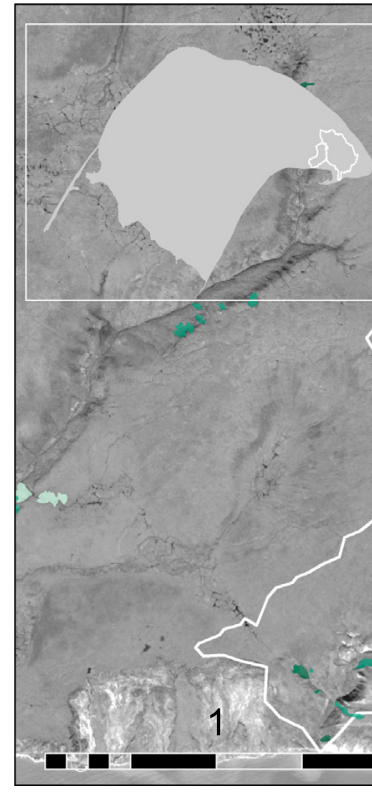

Sampling Sites $\operatorname{SOC}\left(\mathrm{kg} \mathrm{C} \mathrm{m}^{-3}\right)$
$9.9-15.9$
$16.0-22.9$
$23.0-30.0$
$30.5-37.8$
$37.9-46.7$

Fig. 5. Variability in the soil organic carbon content between sampling sites in two of the studied valleys, ICW and FC. The figure also shows hillslope thermokarst (retrogressive thaw slumps and active layer detachments) in 1952, 1972 and 2011 and 2015 (after Coch et al., 2018a, 2018b). All landforms but one were stable in 2011 and 2015. The undelaying image is a WorldView satellite image from August 8th 2015.

$2.1 \pm 0.6 \mathrm{~kg} \mathrm{~N} \mathrm{~m}^{-2}$. These values are lower than previous estimates of mean SOC and TN $0-100 \mathrm{~cm}$ stocks for the entire Herschel Island; $34.8 \mathrm{~kg} \mathrm{C} \mathrm{m}^{-2}$ and $3.4 \mathrm{~kg} \mathrm{~N} \mathrm{~m}^{-2}$, respectively (Obu et al., 2017). The SOC stock in the valleys was in the same range as the stock found in the geomorphic units defined by Obu et al. (2017) as strongly disturbed terrains with occurrence of mass wasting processes $\left(20.9 \mathrm{~kg} \mathrm{C} \mathrm{m}^{-2}\right)$, and was lower than those reported by Siewert (2016) for several sites on Herschel Island. We found strong heterogeneity in the soil physical and geochemical parameters between hillslope positions and slope orientation. We attribute the heterogeneity in soil profiles, SOC, TN, and ground ice storage pattern to geomorphic slope processes such as active layer detachment sliding, retrogressive thaw slumping, and solifluction, which promote degradation and mixing of soil layers on hillslopes.

In the valleys, SOC and $\mathrm{TN}$ stocks and $\mathrm{C} / \mathrm{N}$ ratios decreased from upstream to downstream. We associate this to stream erosion, leading to increasing hillslopes instability in the midstream and downstream sections (Hurst et al., 2012). Upstream sites were characterized by stable peaty soils with impeded drainage and thick vegetation cover, which favored terrain stability and the accumulation of fresh SOM.

\subsection{Processes of carbon accumulation}

The highest SOC and TN stocks were found at the summits and at the toeslopes. We show that much of the variance in the carbon and nitrogen contents and stocks for the summits was explained by differences in cryoturbation in the soil profiles which promoted burial and preservation of SOC. A similar pattern was highlighted by Siewert (2016) for sites on Herschel Island, where cryoturbation was identified as a major component in explaining the strong contrast in SOC density at a scale of meters to tens of meters. Toeslopes also featured large SOC and TN stocks, with less decomposed SOM. In the upstream part of the valleys, the toeslope deposits were alluvium, and the high SOC stocks were associated to high biomass production combined with peat accumulation in poorly drained sites with high topographic wetness index. On the contrary, the backslopes located in the midstream and downstream parts of the valleys and characterized by mass movements had lower SOC and TN stocks. The main processes of carbon accumulation were thus different at the summits and the toeslopes, highlighting the impact of valley topography on the carbon storage.

\subsection{Impact of ALDS and RTS on SOC and $N$ storage at the footslopes}

We show that the differences in SOC and TN storage between the valleys and the rest of the landscape are largely driven by the occurrence of hillslope thermokarst processes. In permafrost terrains, stream incision alters hillslope profiles, triggering erosion at the backslopes and deposition of material downhill. At the footslopes, downslope transport through solifluction, sliding, slumping, and colluvial 
Table 6

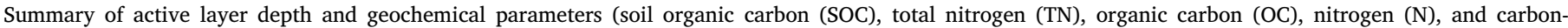

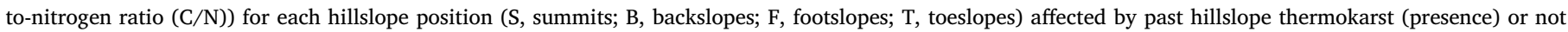
(absence) averaged for the three valleys. Mean values are reported with \pm one standard deviation.

\begin{tabular}{|c|c|c|c|c|c|c|c|c|}
\hline & & Sites (n) & $\mathrm{AL}(\mathrm{cm})$ & $\operatorname{SOC}\left(\mathrm{kg} \mathrm{m}^{2}\right)$ & $\mathrm{TN}\left(\mathrm{kg} \mathrm{m}^{2}\right)$ & OC content (\%) & $\mathrm{N}$ content $(\%)$ & $\mathrm{C} / \mathrm{N}$ \\
\hline \multirow[t]{3}{*}{ S } & Absence & 18 & $41.1 \pm 8.8$ & $27.1 \pm 6.3$ & $2.1 \pm 0.4$ & $9.3 \pm 3.3$ & $0.6 \pm 0.2$ & $13.9 \pm 2.2$ \\
\hline & Presence & 0 & NA & NA & NA & NA & NA & NA \\
\hline & Absence & 13 & $55.2 \pm 17.5$ & $26.6 \pm 9.0$ & $2.3 \pm 0.5$ & $7.3 \pm 2.6$ & $0.5 \pm 0.1$ & $11.9 \pm 1.6$ \\
\hline \multirow[t]{2}{*}{ B } & Presence & 3 & $67.7 \pm 18.5$ & $19.3 \pm 13.1$ & $1.7 \pm 0.9$ & $5.3 \pm 3.5$ & $0.3 \pm 0.2$ & $11.1 \pm 1.2$ \\
\hline & Absence & 1 & $100.0 \pm \mathrm{NA}$ & $22.5 \pm \mathrm{NA}$ & $2.3 \pm \mathrm{NA}$ & $9.2 \pm \mathrm{NA}$ & $0.5 \pm \mathrm{NA}$ & $13.1 \pm \mathrm{NA}$ \\
\hline \multirow[t]{2}{*}{$\mathrm{F}$} & Presence & 3 & $92.7 \pm 12.7$ & $17.2 \pm 7.0$ & $1.7 \pm 0.8$ & $3.6 \pm 2.2$ & $0.3 \pm 0.2$ & $10.2 \pm 0.4$ \\
\hline & Absence & 4 & $43.0 \pm 9.7$ & $34.0 \pm 10.4$ & $2.5 \pm 0.9$ & $10.6 \pm 3.0$ & $0.8 \pm 0.2$ & $13.8 \pm 2.3$ \\
\hline $\mathrm{T}$ & Presence & 1 & $34.0 \pm \mathrm{NA}$ & $32.8 \pm \mathrm{NA}$ & $2.1 \pm \mathrm{NA}$ & $14.1 \pm \mathrm{NA}$ & $0.9 \pm \mathrm{NA}$ & $15.3 \pm N A$ \\
\hline
\end{tabular}

\section{Table 7}

Pearson correlation coefficients between geochemical parameters (soil organic carbon (SOC), total nitrogen (TN), organic carbon (OC), nitrogen (N), and carbon-to-nitrogen ratio $(\mathrm{C} / \mathrm{N})$ ), soil variables and topography (AL, active layer depth; CRY, cryoturbation; VWC, volumetric water content; TWI, topographic wetness index). The means were averaged for the three valleys. Significant relations are indicated in bold and marked according to their significance level: $* * * \mathrm{p}<0.001 ; * * \mathrm{p}<0.05 ; * \mathrm{p}<0.1$.

\begin{tabular}{|c|c|c|c|c|}
\hline & $\mathrm{AL}\left(\mathrm{r}^{2}\right)$ & $\mathrm{CRY}\left(\mathrm{r}^{2}\right)$ & $\operatorname{VWC}\left(\mathrm{r}^{2}\right)$ & TWI $\left(r^{2}\right)$ \\
\hline SOC $\left(\mathrm{kg} \mathrm{m}^{-2}\right)$ & $-0.40 *$ & $0.55 * * *$ & $0.49 *$ & $0.21 *$ \\
\hline $\mathrm{TN}\left(\mathrm{kg} \mathrm{m}^{-2}\right)$ & $-0.12^{*}$ & $0.37^{* *}$ & $0.37^{*}$ & $0.07^{*}$ \\
\hline OC (\%) & $-0.51 * * *$ & $0.71 * * *$ & $0.44 * * *$ & $0.30 * *$ \\
\hline N (\%) & $-0.49 * * *$ & $0.79 * * *$ & 0.52 & $0.36 * * *$ \\
\hline $\mathrm{C} / \mathrm{N}$ & $-0.53^{* * *}$ & $0.66 * * *$ & $0.36 * * *$ & $0.29 * * *$ \\
\hline
\end{tabular}

processes generates thick and compacted soil deposits with deep active layers, resulting in lower SOC and TN stocks (Berhe et al., 2007; Shelef et al., 2017; Yoo et al., 2005). This suggests that in our study area a large part of the SOM and SOC transported from uphill underwent decomposition prior to or during transport to the footslopes, or that in situ decomposition occurred. This pattern is similar to the one observed on backslopes affected by abrupt mass movements (Abbott and Jones, 2015; Cassidy et al., 2016; Grewer et al., 2016; Tanski et al., 2017). In similar permafrost settings, low SOC storage within hillslope thermokarst landforms has been attributed to increased soil temperature and associated to dilution with melted ice, leaching and mineralization (Abbott et al., 2014; Abbott and Jones, 2015; Grewer et al., 2016; Pautler et al., 2010; Tanski et al., 2017). As a result, the SOM in depositional areas is commonly less decomposed than in eroding landform positions, which partly explain the large quantities of SOC stored at the footslopes (Berhe et al., 2012; Shelef et al., 2017). Our results contradict previous research done on hillslope permafrost landscapes, which has shown both SOC accumulation and SOM stabilization in footslope areas (Berhe et al., 2012; Grewer et al., 2015, 2016). In some situations, hillslope thermokarst remove the physical and chemical mechanisms of SOM protection, exposing the soils to decomposition (Abbott et al., 2014; Berhe et al., 2012). It is important to note that we did not capture the whole thickness of deposited sediments on the footslopes. It is possible that the initial soil surfaces were buried below $>1 \mathrm{~m}$, in sediments that were not sampled in this study. Deeper cores would allow to better capture the whole sequence of deposited sediments. These findings highlight the importance of environmental conditions at the footslope for the stability of buried SOM.

\section{Conclusion}

This study highlights the strong spatial variability of SOC and TN storage in sloping terrains of three valleys located on Herschel Island,
Yukon Territory, Canada. The average SOC and TN $0-100 \mathrm{~cm}$ stocks in the valleys were $26.4 \pm 8.9 \mathrm{~kg} \mathrm{C} \mathrm{m}^{-2}$ and $2.1 \pm 0.6 \mathrm{~kg} \mathrm{~N} \mathrm{~m}^{-2}$. The summits and toeslsopes accumulated larger stocks of SOC and TN. Cryoturbation was the main process for SOC accumulation at the summits, while impeded drainage and deposition of fine textured material by slope processes led to peat formation and SOC accumulation at the toeslopes. Geomorphic processes on hillslopes govern soil thickness and provide fundamental mechanisms that control SOM decomposition and SOC distribution patterns on vegetated hillslopes. Sites affected by active layer detachment slides and retrogressive thaw slumps in the past had lower SOC and TN contents, due to degradation of carbon downstream and downslope. However, it is not clear whether the SOM and SOC transported from uphill underwent decomposition during transport to downslope, or that in situ decomposition occurred. Our results highlight the importance of environmental conditions at the footslope for the stability of buried SOM and have wide implications for estimating SOC and TN storage in permafrost landscape.

Supplementary data to this article can be found online at https:// doi.org/10.1016/j.catena.2019.02.029.

\section{Author's contribution}

J.L.R., H.L., and A.M. designed the study. J.L.R. was the main contributor in terms of analyses, wrote the initial version of the paper and made the figures. D.F. provided scientific inputs and feedback to the study design. G.H. took part in the fieldwork and sampling procedure, provided scientific inputs, and contributed to the interpretation of the data. H.L. led the fieldwork campaign and acquired financial support. A.M. provided scientific inputs to the study design. All authors contributed with interpretation of the results and editing of the manuscript. H.L. and A.M. provided guidance and support throughout the study.

\section{Acknowledgements}

This study was supported by the Helmholtz Association through the COPER Young Investigators Group (VH-NG-801) and by the Alfred Wegener Institute in Potsdam, Germany. J. L. Ramage was financially supported by the University of Potsdam through a $\mathrm{PhD}$ stipend. We thank J. Kahl, S. Stettner, G. Tanski, A. M. Irrgang, I. Eischeid and S. Ruttor for their precious support during fieldwork, as well as P. Lahouette and L. Durstewitz for their contribution in the lab. We are grateful to R. Gordon and the rangers of the Qikiqtaruk - Herschel Island - Territorial Park for their support in the field in 2015. This publication is part of the Nunataryuk project. The project has received funding under the European Union's Horizon 2020 research and innovation programme under grant agreement No 773421. The authors also thank the three anonymous reviewers for their useful comments. 


\section{References}

Abbott, B.W., Jones, J.B., 2015. Permafrost collapse alters soil carbon stocks, respiration, $\mathrm{CH}_{4}$, and $\mathrm{N}_{2} \mathrm{O}$ in upland tundra. Glob. Chang. Biol. 21, 4570-4587. https://doi.org/ 10.1111/gcb.13069.

Abbott, B.W., Larouche, J.R., Jones, J.B., Bowden, W., Balser, A.W., 2014. Elevated dissolved organic carbon biodegradability from thawing and collapsing permafrost. J. Geophys. Res. Biogeosci. 119, 2049-2063. https://doi.org/10.1002/2014JG002678.

AMAP, 2017. Snow, Water, Ice and Permafrost in the Arctic (SWIPA). Arctic Monitoring and Assessment Programme (AMAP) Oslo, Norway (269 pp).

Berhe, A.A., Harte, J., Harden, J.W., Torn, M.S., 2007. The significance of the Erosioninduced terrestrial carbon sink. AIBS Bull. 57 (4), 337-346.

Berhe, A.A., Harden, J.W., Torn, M.S., Kleber, M., Burton, S.D., Harte, J., 2012. Persistence of soil organic matter in eroding versus depositional landform positions. J. Geophys. Res. 117, 1-16. https://doi.org/10.1029/2011JG001790.

Bouchard, M., 1974. Surficial Geology of Herschel Island, Yukon Territory. Doctoral dissertation, M. Sc. thesis. University of Montréal (70 pp).

Burn, C.R., 2000. The thermal regime of a retrogressive thaw slump near Mayo, Yukon Territory. Can. J. Earth Sci. 37, 967-981. https://doi.org/10.1139/e00-017.

Burn, C., 2012. Permafrost distribution and stability. Chang. Cold Environ. A Can. Perspect. 126-146. https://doi.org/10.1002/9781119950172.ch7.

Burn, C.R., Zhang, Y., 2009. Permafrost and climate change at Herschel Island (Qikiqtaruq), Yukon Territory, Canada. J. Geophys. Res. Earth Surf. 114, 1-16. https://doi.org/10.1029/2008JF001087.

Cassidy, A.E., Christen, A., Henry, G.H.R., 2016. The effect of a permafrost disturbance on growing-season carbon-dioxide fluxes in a high Arctic tundra ecosystem. Biogeosciences 13, 2291-2303. https://doi.org/10.5194/bg-13-2291-2016.

Coch, C., Lamoureux, S., Knoblauch, C., Eischeid, I., Fritz, M., Obu, J., Lantuit, H., 2018a. Summer rainfall DOC, solute and sediment fluxes in a small Arctic coastal catchment on Herschel Island (Yukon Territory, Canada). Arct. Sci. 10.

Coch, C., Ramage, J.L., Lamoureux, S., Meyer, H., Knoblauch, C., Lantuit, H., 2018b. Hydrochemistry, runoff and mapped disturbances of low arctic watersheds on Herschel Island, Yukon Territory, Canada. J. Geophys. Res. Biogeosci (submitted).

Couture, N.J., Pollard, W.H., 2017. A model for quantifying ground-ice volume, Yukon Coast, Western Arctic Canada. Permafr. Periglac. Process. 28, 534-542. https://doi. org/10.1002/ppp.1952.

Environment Canada, 2017. Canadian Climate Normals 1971-2000 Station Data. Available from: http://climate.weather.gc.ca/climate normals.

Grewer, D.M., Lafrenière, M.J., Lamoureux, S.F., Simpson, M.J., 2015. Potential shifts in Canadian High Arctic sedimentary organic matter composition with permafrost active layer detachments. Org. Geochem. 79, 1-13. https://doi.org/10.1016/j. orggeochem.2014.11.007.

Grewer, D.M., Lafrenière, M.J., Lamoureux, S.F., Simpson, M.J., 2016. Redistribution of soil organic matter by permafrost disturbance in the Canadian High Arctic. Biogeochemistry 128, 397-415. https://doi.org/10.1007/s10533-016-0215-7.

Gruber, S., 2012. Derivation and analysis of a high-resolution estimate of global permafrost zonation. Cryosphere 6, 221-233. https://doi.org/10.5194/tc-6-221-2012.

Guisan, A., Weiss, S.B., Weiss, A.D., 1999. GLM versus CCA spatial modeling of plant species distribution. Plant Ecol. 143, 107-122.

Hugelius, G., Strauss, J., Zubrzycki, S., Harden, J.W., Schuur, E. a G., Ping, C., Schirrmeister, L., 2014. Estimated stocks of circumpolar permafrost carbon with quantified uncertainty ranges and identified data gaps. Biogeosciences 11 , 6573-6593. https://doi.org/10.5194/bg-11-6573-2014.

Hurst, M.D., Mudd, S.M., Walcott, R., Attal, M., Yoo, K., 2012. Using hilltop curvature to derive the spatial distribution of erosion rates. J. Geophys. Res. 117, 1-19. https:// doi.org/10.1029/2011JF002057.

Kokelj, S.V., Lacelle, D., Lantz, T.C., Tunnicliffe, J., Malone, L., Clark, I.D., Chin, K.S., 2013. Thawing of massive ground ice in mega slumps drives increases in stream sediment and solute flux across a range of watershed scales. J. Geophys. Res. Earth Surf. 118, 681-692. https://doi.org/10.1002/jgrf.20063.

Koven, C.D., Lawrence, D.M., Riley, W.J., 2015. Permafrost carbon - climate feedback is sensitive to deep soil carbon decomposability but not deep soil nitrogen dynamics. Proc. Natl. Acad. Sci. 112 (12), 3752-3757. https://doi.org/10.1073/pnas. 1415123112

Kuhry, P., Vitt, D.H., 1996. Fossil carbon/nitrogen ratios as a measure of peat decomposition. Ecology 77 (1), 271-275.

Lamoureux, S.F., Lafrenière, M.J., 2009. Fluvial impact of extensive active layer detachments, Cape Bounty, Melville Island, Canada. Arctic, Antarct. Alp. Res. 41, 59-68. https://doi.org/10.1657/1938-4246(08-030).

Lamoureux, S.F., Lafrenière, M.J., 2014. Seasonal fluxes and age of particulate organic carbon exported from Arctic catchments impacted by localized permafrost slope disturbances. Environ. Res. Lett. 9, 45002. https://doi.org/10.1088/1748-9326/9/4/ 045002.

Lantuit, H., Pollard, W.H., 2008. Fifty years of coastal erosion and retrogressive thaw slump activity on Herschel Island, southern Beaufort Sea, Yukon Territory, Canada. Geomorphology 95, 84-102. https://doi.org/10.1016/j.geomorph.2006.07.040.

Lantz, T.C., Kokelj, S.V., 2008. Increasing rates of retrogressive thaw slump activity in the
Mackenzie Delta region, N.W.T., Canada. Geophys. Res. Lett. 35, 1-5. https://doi. org/10.1029/2007GL032433.

Larouche, J.R., Abbott, B.W., Bowden, W.B., Jones, J.B., 2015. The role of watershed characteristics, permafrost thaw, and wildfire on dissolved organic carbon biodegradability and water chemistry in Arctic headwater streams. Biogeosciences 12, 4221-4233. https://doi.org/10.5194/bg-12-4221-2015.

MacKay, J.R., 1959. Glacier ice thrust features of the Yukon coast. Geogr. Bull. 13, 5-21.

Mishra, U., Jastrow, J.D., Matamala, R., Hugelius, G., Koven, C.D., Harden, J.W., Ping, C. L., Michaelson, G.J., Fan, Z., Miller, R.M., McGuire, a.D., Tarnocai, C., Kuhry, P., Riley, W.J., Schaefer, K., Schuur, E.A.G., Jorgenson, M.T., Hinzman, L.D., 2013. Empirical estimates to reduce modeling uncertainties of soil organic carbon in permafrost regions: a review of recent progress and remaining challenges. Environ. Res. Lett. 8. https://doi.org/10.1088/1748-9326/8/3/035020.

Obu, J., Lantuit, H., Grosse, G., Günther, F., Sachs, T., Helm, V., Fritz, M., 2016. Coastal erosion and mass wasting along the Canadian Beaufort Sea based on annual airborne LiDAR elevation data. Geomorphology 293, 331-346. https://doi.org/10.1016/j. geomorph.2016.02.014.

Obu, J., Lantuit, H., Heim, B., Wolter, J., Fritz, M., 2017. Effect of terrain characteristics on soil organic carbon and Total nitrogen stocks in soils of Herschel Island, Western Canadian Arctic. Permafr. Periglac. Process. 28, 92-107. https://doi.org/10.1002/ ppp. 1881.

Palmtag, J., Ramage, J., Hugelius, G., Gentsch, N., Laschinskiy, N., Richter, A., Kuhry, P., 2016. Controls on the storage of organic carbon in permafrost soil in northern Siberia. Eur. J. Soil Sci. 67, 478-491. https://doi.org/10.1111/ejss.12357.

Pautler, B.G., Simpson, J., Mcnally, D.J., Lamoureux, S.F., 2010. Arctic permafrost active layer detachments stimulate microbial activity and degradation of soil organic matter. Environ. Sci. Technol. 44, 4076-4082. https://doi.org/10.1021/es903685j.

Pollard, W., 1990. The nature and origin of ground ice in the Herschel Island area, Yukon Territory. In: Proc. Fifth Can. Conf. Permafr, pp. 23-30.

Ramage, J.L., 2017. Valleys of Herschel Island, Yukon, Canada. PANGEA Dataset. https:// doi.org/10.1594/PANGAEA.883524.

Rudy, A.C. a, Lamoureux, S.F., Treitz, P., Collingwood, A., 2013. Identifying permafrost slope disturbance using multi-temporal optical satellite images and change detection techniques. Cold Reg. Sci. Technol. 88, 37-49. https://doi.org/10.1016/j. coldregions.2012.12.008.

Schädel, C., Schuur, E.A., Bracho, R., Elberling, B., Knoblauch, C., Lee, H., Luo, Y., Shaver, G.R., Turetsky, M.R., 2014. Circumpolar assessment of permafrost C quality and its vulnerability over time using long-term incubation data. Glob. Chang. Biol. 20 (2), 641-652.

Schaefer, K., Lantuit, H., Romanovsky, V.E., Schuur, E. a G., Witt, R., 2014. The impact of the permafrost carbon feedback on global climate. Environ. Res. Lett. 9, 85003. https://doi.org/10.1088/1748-9326/9/8/085003.

Schoeneberger, P.J., Wysocki, D.A., Benham, E.C., 2012. Soil Staff Survey. In: Field Book for Describing and Sampling Soils, Version 3.0. Natural Re, Lincoln, NE.

Schuur, E.A.G., McGuire, A.D., Schädel, C., Grosse, G., Harden, J.W., Hayes, D.J., Hugelius, G., Koven, C.D., Kuhry, P., Lawrence, D.M., Natali, S.M., Olefeldt, D., Romanovsky, V.E., Schaefer, K., Turetsky, M.R., Treat, C.C., Vonk, J.E., 2015. Climate change and the permafrost carbon feedback. Nature 520, 171-179. https://doi.org/ 10.1038/nature14338.

Shelef, E., Rowland, J.C., Wilson, C.J., 2017. Large uncertainty in permafrost carbon stocks due to hillslope soil deposits. Geophys. Res. Lett. 44, 1-11. https://doi.org/10. 1002/2017GL073823.

Siewert, M.B., 2016. High-Resolution Mapping and Spatial Variability of Soil Organic Carbon Storage in Permafrost Environments. Dissertations from the Department of Physical Geography. Department of Physical Geography, Stockholm University.

Siewert, M., Hanisch, J., Weiss, N., Kuhry, P., Maximov, T., Hugelius, G., 2015. Comparing carbon storage of Siberian tundra and taiga permafrost ecosystems at very high spatial resolution. J. Geophys. Res. Biogeosci. 120, 1973-1994. https://doi.org/ 10.1002/2015JG002999.

Smith, C., Kennedy, C., Hargrave, A., McKenna, K., 1989. Soil and Vegetation of Herschel Island, Yukon Territory - Yukon Soil Survey Report. Ottawa.

Soil Classification Working Group, C.A.S.C.C, 1998. The Canadian System of Soil Classification. NRC Research press.

Tanski, G., Lantuit, H., Ruttor, S., Knoblauch, C., Radosavljevic, B., Strauss, J., Wolter, J., Irrgang, A.M., Ramage, J., Fritz, M., 2017. Transformation of terrestrial organic matter along thermokarst-affected permafrost coasts in the Arctic. Sci. Total Environ. 581-582, 434-447. https://doi.org/10.1016/j.scitotenv.2016.12.152.

Woo, M., 1986. Permafrost hydrology in North America. Atmosphere-Ocean 24, 201-234. https://doi.org/10.1080/07055900.1986.9649248.

Woods, G.C., Simpson, M.J., Pautler, B.G., Simpson, J., Lamoureux, S.F., Lafrenière, M.J., 2011. Evidence for the enhanced lability of dissolved organic matter following permafrost slope disturbance in the Canadian high Arctic. Geochim. Cosmochim. Acta 75, 7226-7241. https://doi.org/10.1016/j.gca.2011.08.013.

Yoo, K., Amundson, R., Heimsath, A.M., Dietrich, W.E., 2005. Erosion of upland hillslope soil organic carbon: coupling field measurements with a sediment transport model. Glob. Biogeochem. Cycles 19. https://doi.org/10.1029/2004GB002271. 